\title{
Erratum to: Application of renewable energy sources and new building technologies for the Philippine single family detached house
}

\author{
Napoleon Enteria ${ }^{1} \cdot$ Hazim Awbi $^{2} \cdot$ Hiroshi Yoshino ${ }^{3}$
}

Published online: 2 July 2015

(C) The Author(s) 2015. This article is published with open access at Springerlink.com

\section{Erratum to: Int J Energy Environ Eng DOI 10.1007/s40095-015-0174-0}

The sensible power component of the total cooling load of the air-conditioning system is

$\dot{Q}_{\mathrm{SE}(\mathrm{CL})}=\dot{m}_{\mathrm{SA}} C_{P(\mathrm{SA})}\left(T_{1}-T_{6}\right)$
The sensible power component of the total cooling effect of the air-conditioning system in the house is

$\dot{Q}_{\mathrm{SE}(\mathrm{CE})}=\dot{m}_{\mathrm{SA}} C_{P(\mathrm{SA})}\left(T_{7}-T_{6}\right)$

Open Access This article is distributed under the terms of the Creative Commons Attribution License which permits any use, distribution, and reproduction in any medium, provided the original author(s) and the source are credited.

The online version of the original article can be found under doi:10.1007/s40095-015-0174-0.

Napoleon Enteria

enterian2@asme.org; nenteria@yahoo.com

Enteria Grün Energietechnik, Davao 8000, Philippines

2 University of Reading, Reading RG6 6AH, UK

3 Architectural Institute of Japan, Tokyo 108-8414, Japan 